[Chem. Pharm. Bull.

35( 2 ) $861-864(1987)]$

\title{
Studies on Antihemorrhagic Substances in Herbs Classified as Hemostatics in Chinese Medicine. VII. On the Antihemorrhagic Principle in Cirsium japonicum DC. ${ }^{1}$
}

\author{
Hitoshi Ishida, * TAKAYUKI UMINO, KUniRo TSUJI \\ and TAKUO KOSUGE \\ Shizuoka College of Pharmacy, 2-2-1 Oshika, \\ Shizuoka 422, Japan
}

(Received July 17, 1986)

\begin{abstract}
The antihemorrhagic principle in Cirsium japonicum DC. was isolated by partition, gel filtration on Sephadex LH-20 and silica gel column chromatography, and identified as pectolinarin [7-[6-O-(6-deoxy- $\beta$-mannopyranosyl)- $\beta$-D-glucopyranosyl]-5, 7-dihydroxy-6-methoxy-2-(4methoxyphenyl)- $4 H-1$-benzopyran-4-one].
\end{abstract}

Keywords- hemostatic; Cirsium japonicum; antihemorrhagic principle; pectolinarin

In the previous paper, we reported that the antihemorrhagic principle had been isolated from Sophora japonica L., which is one of the herbs used as hemostatics in Chinese medicine, and identified as quercetin. ${ }^{1)}$ The present paper describes the isolation of the antihemorrhagic principle in Cirsium japonicum DC.

Cirsium japonicum DC. is an important herb, used as an antihemorrhagic agent and uretic in Chinese medicine. ${ }^{2)}$ Previous work on the herb focused only on the chemical components, such as pectolinarin and acetin rhamnoglucoside, ${ }^{3)}$ and no pharmacological study on the antihemorrhagic principle in the herb has been reported. We would like to describe here the isolation and identification of the hemostatically active principle in the herb.

In the isolation process, Tajima et al.'s method $^{4)}$ with mice was used to follow the antihemorrhagic activity of the material. ${ }^{5)}$ Isolation of the active principle was achieved by partition, gel filtration through Sephadex LH-20 and column chromatography over silica gel. The procedures are summarized in Chart 1.

As shown in Chart 1, ground herb of Cirsium japonicum DC. was extracted with water. The extract was partitioned between $n$-butanol and water. The activity emerged only in the $n$ butanol layer (active fraction I). By using a small quantity of methanol, this fraction was fractionated into soluble and insoluble parts, namely fraction $\mathrm{II}_{1}$ and fraction $\mathrm{II}_{2}$. The activity emerged in both fractions. Firstly, we dealt with fraction $\mathrm{II}_{1}$, because it showed higher antihemorrhagic activity than fraction $\mathrm{II}_{2}$. The active fraction $\mathrm{II}_{1}$ was subjected to Sephadex LH-20 column chromatography with methanol. The elution pattern and activities of the fractions are shown in Fig. 1. As the activity was present only in fraction III $\left(K_{d}\right.$ value $=1.14-1.76$ ), this was chromatographed over silica gel to afford highly active fraction IV. After gel filtration of this fraction through Sephadex LH-20, the product was recrystallized from methanol to afford the active principle as light yellow needles. This active principle was also obtained by silica gel column chromatography of the hot methanol extract of fraction $\mathrm{II}_{2}$, as shown in Chart 1 . Thin layer chromatograms of fractions $\mathrm{II}_{1}, \mathrm{II}_{2}, \mathrm{III}$ and IV, and the active principle on silica gel are shown in Fig. 2. As shown in Figs. 1 and 2, the combination of column chromatographies is very effective for the purification of the active principle. 


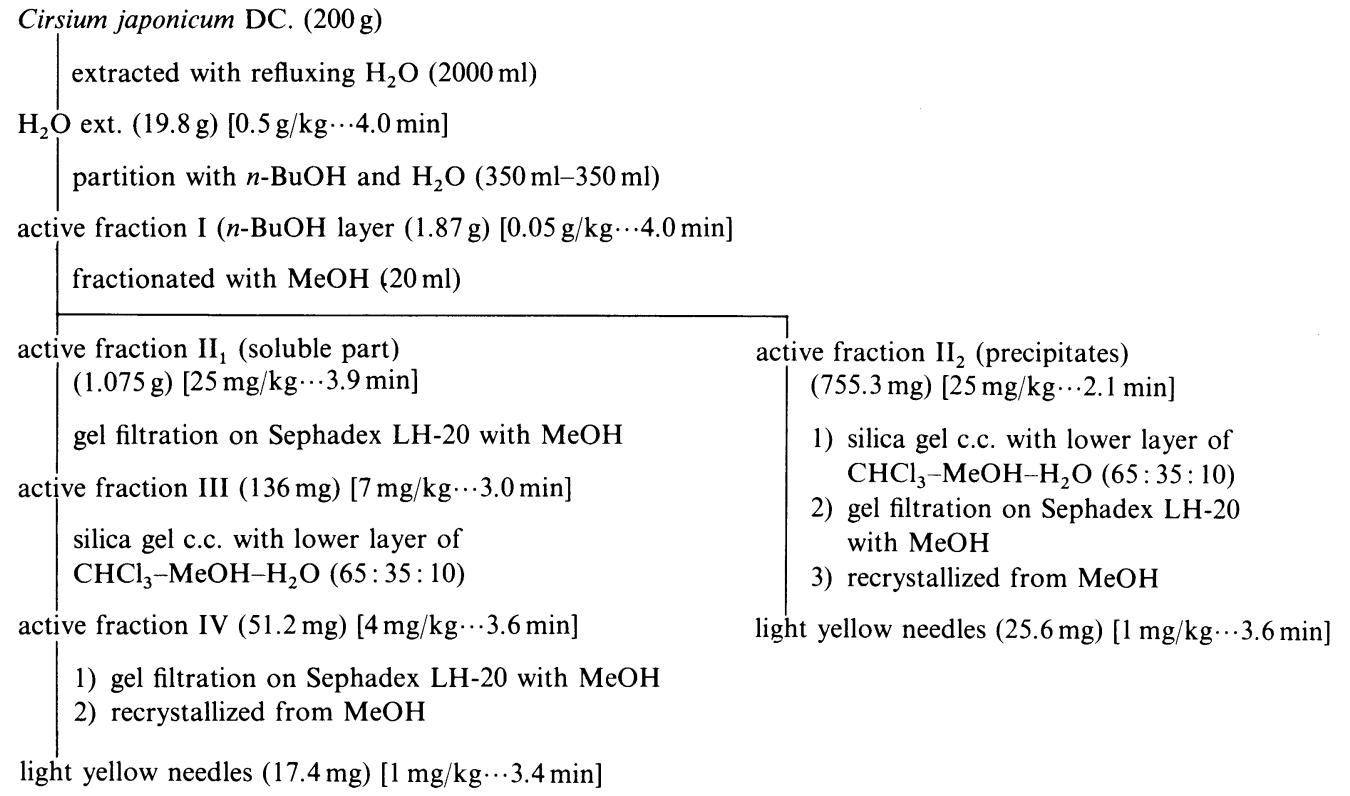

( ) indicates yield. [ ] indicates dose and activity (shortening of bleeding time). Silica gel c.c., silica gel column chromatography.

Chart 1. Isolation of the Active Principle

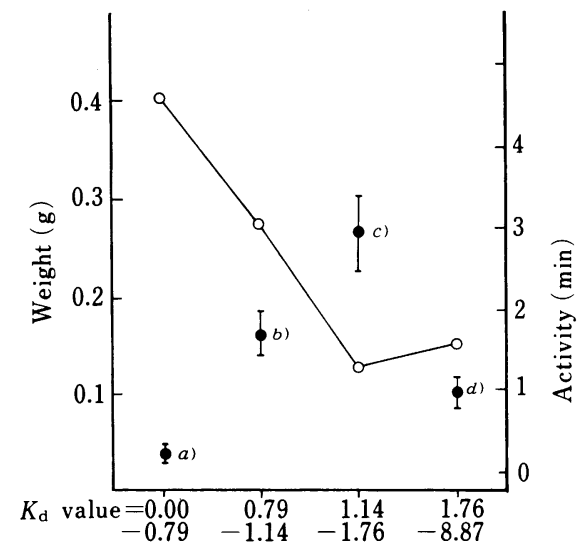

Fig. 1. Elution Pattern of the $n-\mathrm{BuOH}$ Layer $(1.07 \mathrm{~g})$ on a Sephadex LH-20 Column $(4.4 \times$ $80 \mathrm{~cm})$ and Activities of the Fractions

$\mathrm{O}-\mathrm{O}$, chromatogram; $\bullet$, activity (shortening of bleeding time after i.p. administration at each dose [a) $0.042, b) 0.030, c) 0.007, d) 0.017 \mathrm{~g} / \mathrm{kg}$ weight]). Each point represents the mean of the antihemorrhagic activity in five different experiments with the S.E. indicated.

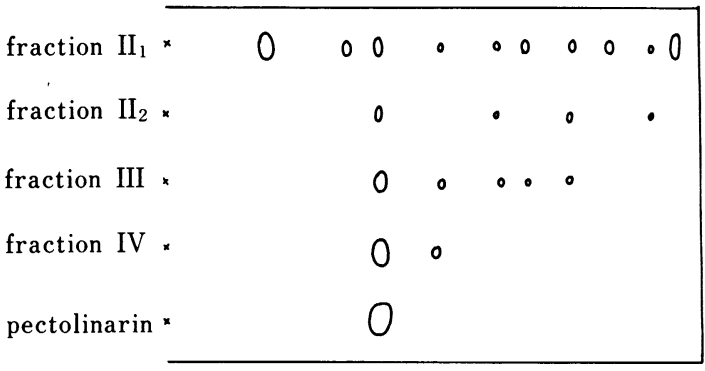

Fig. 2. Thin Layer Chromatograms of Fractions $\mathrm{II}_{1}, \mathrm{II}_{2}$, III and IV, and Pectolinarin

Plate: Kieselgel H60 (Merck Art. 5721). Solvent: lower layer of $\mathrm{CHCl}_{3}-\mathrm{MeOH}-\mathrm{H}_{2} \mathrm{O}(65: 35: 10)$.

From the spectral data (nuclear magnetic resonance (NMR), infrared (IR), mass (MS) and ultraviolet (UV)), the active principle was apparently identical with pectolinarin [7-[6-O(6-deoxy- $\beta$-mannopyranosyl)- $\beta$-D-glucopyranosyl]-5,7-dihydroxy-6-methoxy-2-(4methoxyphenyl)-4H-1-benzopyran-4-one]. This was confirmed by a direct comparison (mp, 
NMR, MS, IR and UV) with an authentic sample. The antihemorrhagic activity of the authentic sample is equal to that of the natural product.

Pectolinarin has been isolated from leaves of Sophora angustifolia SIEB. et ZUCC,6) Cirsium microspicatum, C. otayae, C. Yoshizawae, C. olderaceum, and Lindra japonica ${ }^{3)}$ and dried plant of Lindra vulgaris L. ${ }^{7)}$ There has been no pharmacological study of pectolinarin, so this is the first report that pectolinarin has a biological (hemostatic) activity in vivo.

In summary, we have identified pectolinarin as a hemostatically active principle of Cirsium japonicum DC.

\section{Experimental}

The melting point is uncorrected. The IR spectrum was recorded on a JASCO IRA-2 grating IR spectrophotometer. Proton and carbon-13 nuclear magnetic resonance $\left({ }^{1} \mathrm{H}-\right.$ and $\left.{ }^{13} \mathrm{C}-\mathrm{NMR}\right)$ spectra were recorded with a JEOL FX-90 Fourier-transform nuclear magnetic spectrometer and are calibrated in parts per million $(\delta)$ downfield from tetramethylsilane as an internal standard. The MS were recorded on a Hitachi M-80A instrument. The UV spectrum was recorded on a Shimadzu UV-360 recording spectrophotometer.

Assay of Hemostatic Activity- Hemostatic tests were carried out by Tajima et al.'s method ${ }^{4)}$ on male mice weighing $18-20 \mathrm{~g}$. Test material homogenized in $1 \%$ methylcellulose $-0.9 \%$ sodium chloride aq. was given interperitoneally by injection. The bleeding time was determined according to Tajima et al.'s method.4)

Material - The herb used in this study was a commercial product available in China and was identified as Cirsium japonicum DC. by an expert.

Extraction- Ground herb of Cirsium japonicum DC. $(200 \mathrm{~g})$ was extracted with 21 of water under reflux for $30 \mathrm{~min}$. The mixture was centrifuged at $2500 \mathrm{rpm}$ for $20 \mathrm{~min}$ and the supernatant was lyophilized to afford brown needles $(19.8 \mathrm{~g})$.

Partition between $\boldsymbol{n}$-Butanol and Water- The crude extract $(19.8 \mathrm{~g})$ was dissolved in $350 \mathrm{ml}$ of water and extracted with $350 \mathrm{ml}$ of $n$-butanol three times. Concentration of the upper layer under reduced pressure afforded active fraction $\mathrm{I}(1.87 \mathrm{~g})$.

Gel Filtration on Sephadex LH-20 Active fraction I $(1.87 \mathrm{~g})$ was fractionated into the soluble part (fraction $\left.\mathrm{II}_{1}\right)(1.075 \mathrm{~g})$ and precipitates (fraction $\left.\mathrm{II}_{2}\right)(0.755 \mathrm{~g})$ with $20 \mathrm{ml}$ of methanol. Fraction $\mathrm{II}_{1}$ was subjected to gel filtration through Sephadex LH-20 $(4.4 \times 80 \mathrm{~cm})$ with methanol to afford active fraction III $\left(K_{\mathrm{d}}\right.$ value $\left.=1.14-1.76\right)$ (136.4 mg).

Silica Gel Column Chromatography of Active Fraction III-Active fraction III (136.4 mg) was chromatographed over silica gel $(2.3 \times 14 \mathrm{~cm})$ with the lower layer of $\mathrm{CHCl}_{3}-\mathrm{MeOH}-\mathrm{H}_{2} \mathrm{O}(65: 35: 10)$ as an eluent to afford active fraction IV $(51.2 \mathrm{mg})$.

Recrystallization of Active Fraction- Active fraction V (fractions with $K_{\mathrm{d}}$ value $\left.=1.00-1.20\right)(24.1 \mathrm{mg})$ was obtained by Sephadex LH-20 $(2.1 \times 30 \mathrm{~cm})$ column chromatography of active fraction IV $(51.2 \mathrm{mg})$ with methanol. This product was recrystallized from methanol to afford the active principle as light yellow needles $(17.1 \mathrm{mg})$. The physical properties are described below.

Column Chromatography of Active Fraction $\mathrm{II}_{2}$ on Silica Gel-Active fraction $\mathrm{II}_{2}(755 \mathrm{mg})$ was extracted with methanol $(50 \mathrm{ml})$ under reflux twice to give a light brown gum $(240.6 \mathrm{mg})$. Column chromatography of this extract over silica gel $(2.3 \times 17 \mathrm{~cm})$, using the lower layer of $\mathrm{CHCl}_{3}-\mathrm{MeOH}-\mathrm{H}_{2} \mathrm{O}(65: 35: 10)$ as an eluent, gave a product $(51.4 \mathrm{mg})$ which contained a component with the same $R f$ value as the active principle. This fraction was gel-filtered through Sephadex LH-20 with methanol to afford a fraction with $K_{\mathrm{d}} 1.00-1.25$. Recrystallization from methanol gave yellow needles $(25.6 \mathrm{mg})$. This product was identified as pectolinarin by direct comparison with an authentic sample.

Identification of the Active Principle - The active compound has the following properties. mp $241-244{ }^{\circ} \mathrm{C}$ $\left(248-250^{\circ} \mathrm{C}\right) .^{6}{ }^{6}$ Anal Calcd for $\mathrm{C}_{29} \mathrm{H}_{34} \mathrm{O}_{15}$ : C, 55.94; H, 5.50. Found: C, 55.67; H, 5.57. MS $m / z: 314,299,271,133$, 69. High resolution MS: 314.0799 (error $-1.0 \mathrm{mMU}$ ) for $\mathrm{C}_{17} \mathrm{H}_{14} \mathrm{O}_{6}$. ${ }^{1} \mathrm{H}-\mathrm{NMR}$ (in DMSO- $d_{6}$ ) $\delta$ (ppm): $12.95-12.50$ $(1 \mathrm{H}, \mathrm{br}), 8.04(2 \mathrm{H}, \mathrm{d}, J=8.8 \mathrm{~Hz}), 7.16(2 \mathrm{H}, \mathrm{d}, J=8.8 \mathrm{~Hz}), 6.92(2 \mathrm{H}, \mathrm{s}), 5.6-4.2(8 \mathrm{H}, \mathrm{m}), 3.86(3 \mathrm{H}, \mathrm{s}), 3.77(3 \mathrm{H}, \mathrm{s})$, $4.0-3.5(2 \mathrm{H}, \mathrm{m}), 1.05(3 \mathrm{H}, \mathrm{d}, J=7.7 \mathrm{~Hz})$. Other signals overlapped with those of the solvent. IR $v_{\max }^{\mathrm{KBr}} \mathrm{cm}^{-1}: 3400$, 2930, 1660,1640,1460,1355,1295, 1180, 835. UV $\lambda_{\max }^{\mathrm{MeOH}} \mathrm{nm}(\log \varepsilon): 272$ (4.18), 327 (4.33).

The active compound was identified as pectolinarin by direct comparison of the physical properties with those of an authentic sample.

Acetylation of Pectolinarin - The natural product $(10 \mathrm{mg})$ was acetylated with pyridine $(1.5 \mathrm{ml})$ and acetic anhydride $(3 \mathrm{ml})$ at $90^{\circ} \mathrm{C}$ for $1 \mathrm{~h}$. Recrystallization of the crude product from dilute methanol gave the heptaacetylated derivative of pectolinarin as white needles $(16 \mathrm{mg})$. This derivative has the following properties. $\mathrm{mp} 131-$ $133^{\circ} \mathrm{C}\left(130-135^{\circ} \mathrm{C}\right) .^{6}{ }^{\prime}$ Anal. Calcd for $\mathrm{C}_{43} \mathrm{H}_{48} \mathrm{O}_{22}$ : C, 56.33; H, 5.27. Found: C, 55.80; H, 5.17. MS $\mathrm{m} / z: 356,314$, $273,213,171,153,127 .{ }^{1} \mathrm{H}-\mathrm{NMR}$ (in $\left.\mathrm{CDCl}_{3}\right) \delta(\mathrm{ppm}): 7.80(2 \mathrm{H}, \mathrm{d}, J=8.8 \mathrm{~Hz}), 7.06(1 \mathrm{H}, \mathrm{s}), 7.00(2 \mathrm{H}, \mathrm{d}, J=8.8 \mathrm{~Hz})$, 
$6.51(1 \mathrm{H}, \mathrm{s}), 4.6-5.5(10 \mathrm{H}, \mathrm{m}), 3.88(3 \mathrm{H}, \mathrm{s}), 3.6-4.1(2 \mathrm{H}, \mathrm{m}), 3.82(3 \mathrm{H}, \mathrm{s}), 2.47(3 \mathrm{H}, \mathrm{s}), 2.05(15 \mathrm{H}, \mathrm{s}), 1.85(3 \mathrm{H}, \mathrm{s})$, $1.18(3 \mathrm{H}, \mathrm{d}, J=6.6 \mathrm{~Hz}) .{ }^{13} \mathrm{C}-\mathrm{NMR}\left(\mathrm{in} \mathrm{CDCl}_{3}\right) \delta(\mathrm{ppm}): 176.4(\mathrm{~s}), 170.1$ (s), $169.9(\mathrm{~s}), 169.7$ (s), 169.3 (s), 169.1 (s), $162.4(\mathrm{~s}), 154.2(\mathrm{~s}), 153.3(\mathrm{~s}), 142.7$ (s), 140.7 (s), 128.0 (d), 123.7 (s), 114.5 (d), 113.7 (d), 106.8 (d), 103.3 (d), 99.3 (d), 98.0 (s), 73.5 (d), 72.4 (d), 70.9 (d), 69.5 (d), 69.0 (d), 66.4 (d), 61.8 (d), 55.5 (d), 21.0 (q), 20.6 (q), 17.4 (q). IR $v_{\max }^{\mathrm{KBr}} \mathrm{cm}^{-1}: 2940,1755,1640,1220,835 . \mathrm{UV} \lambda_{\max }^{\mathrm{MeOH}} \mathrm{nm}(\log \varepsilon): 257$ (4.13), 318 (4.44).

Acknowledgments We are grateful to Prof. Naotaka Morita, Toyama Medical and Pharmaceutical University, for providing an authentic sample of pectolinarin, and to Mr. M. Yamamoto, Shizuoka Prefectural Institute of Public Health and Environmental Science, for obtaining the MS.

\section{References}

1) Part VI: T. Kosuge, H. Ishida, T. Umino and K. Tsuji, Chem. Pharm. Bull., 35, 857 (1987)

2) K. Akamatsu, "Wakanyaku," Ishiyaku Publications, Tokyo, 1966, p. 23; Kobe Chuyakugaku Kenkyukai, "Kanyaku No Rinsyoouyou," Ishiyaku Publications, Tokyo, 1979, p. 241.

3) T. Nakaoki and N. Morita, Yakugaku Zasshi, 79, 1338 (1959); idem, ibid., 80, 1296 (1960); N. Morita and M. Shimizu, ibid., 83, 615 (1962).

4) T. Tajima, T. Ohgoh and K. Miyao, Nippon Yakurigaku Zasshi, 67, 478 (1971).

5) T. Kosuge, M. Yokota and A. Ochiai, Yakugaku Zasshi, 101, 629 (1981).

6) T. Nakaoki, N. Morita, H. Mototsune, A. Hiraki and T. Takeuchi, Yakugaku Zasshi, 75, 172 (1955).

7) G. Zemplen, R. Bogner and L. Mester, Ber., 75B, 489 (1942). 